\title{
HUKUMAN BAGI PELAKU PERKOSAAN MELALUI ANUS (ANAL SEX): Perspektif Fikih Jinayah dan Hukum Pindana Indonesia
}

\author{
Ubaidillah Al Masyariqi \\ Institut Agama Islam Negeri (IAIN) Purwokerto Jawa Tengah \\ E-mail:ubaidillah.2291@gmail.com
}

\begin{abstract}
This article examines anal rape, one of the most often ignored by modern criminal jurists. There are two things studied, namely how Indonesian criminal law view penalties for rape perpetrators through anal (anal sex)? And what about jināyäh jurisprudence about punishment for rape perpetrators through anal (anal sex)? This article is a library research. The data obtained were analyzed by analytical descriptive method and content analysis. After that, it is computed based on the perspective of criminal law and figh law. The results of the study yielded two findings. First, in criminal law, anal sex rape is juridically categorized as obscene acts, so the perpetrator is only sentenced to a maximum of 9 years in prison, 3 years lighter than the threat of intra vaginal rape for 12 years. Secondly, in jināyäh jurisprudence, if based on jikhur ulama's jurisprudence, the penalty for anal sex rape perpetrators is hadd zina punishment and coupled with the penalty of payment of dowry to the victim, there is no difference with intra vaginal rape penalty. If based on the doctrine of al-Hanafiyyah cleric, then the punishment for the perpetrators of anal sex rape is ta'zir penalty, but there is no penalty of dowry payment.
\end{abstract}

Key Words: Anal Sex Rape; Dowry; Hadd Zina; Ta'zir

\begin{abstract}
ABSTRAK
Artikel ini mengkaji tentang salah satu bentuk perkosaan, yang paling sering diabaikan oleh para ahli hukum pidana di abad modern ini, yaitu perkosaan melalui anus (anal sex). Ada dua hal yang dikaji, yaitu bagaimana pandangan hukum pidana Indonesia tentang hukuman bagi pelaku perkosaan melalui anus (anal sex)? Dan bagaimana pandangan
\end{abstract}


fikih jināyāh tentang hukuman bagi pelaku perkosaan melalui anus (anal sex)? Artikel ini merupakan penelitian kepustakaan (library research). Data-yang diperoleh dianalisa berdasarkan metode deskriptif analitis dan content analysis. Setelah itu, dikomparasikan berdasarkan sudut pandang hukum pidana dan hukum fikih. Hasil studi menghasilkan dua temuan. Pertama, di dalam hukum pidana, perkosaan anal sex secara yuridis dikategorikan sebagai perbuatan cabul, sehingga pelakunya hanya diganjar hukuman maksimal 9 tahun penjara, 3 tahun lebih ringan dibandingkan dengan ancaman pidana perkosaan intra vaginal selama 12 tahun. Kedua, di dalam fikih jināyāh, jika mendasarkan pada fikih jumhur ulama, hukuman bagi pelaku perkosaan anal sex adalah hukuman hadd zina dan ditambah dengan hukuman pembayaran mahar kepada korban, tidak ada perbedaan dengan hukuman perkosaan intra vaginal. Jika mendasarkan pada doktrin ulama al-Ḥanafiyyah, maka hukuman bagi pelaku perkosaan anal sex adalah hukuman ta'zir, namun tidak terdapat hukuman pembayaran mahar.

Kata kunci: Anal Sex; Hadd Zina; Mahar; Perkosaan; Ta 'zīr

\section{A. Pendahuluan}

Badan Pusat Statistik (BPS) merilis dalam Laporan Statistik Kriminal 2015, kejahatan terhadap kesusilaan yang terjadi di seluruh Indonesia per tahun 2014 adalah sejumlah 5.499 kasus, terdiri dari kasus perkosaan sejumlah 1.715 kasus, dan pencabulan sejumlah 3.784 kasus (BPS, 2015: 37). Dengan demikian, setidaknya, dalam satu hari, rata-rata terjadi empat kasus perkosaan dan sepuluh kasus pencabulan di seluruh wilayah Republik Indonesia.

Sayangnya, di tengah tingginya angka kejahatan di bidang seksual tersebut, hukum pidana materil yang masih diberlakukan di Indonesia tampaknya sudah tidak relevan dengan bentuk dan modus kejahatan seksual yang terjadi di lapangan. Penelitian yang dilakukan oleh Komisi Nasional Anti Kekerasan terhadap Perempuan (Komnas Perempuan) menyimpulkan, bahwa sejak tahun 1998-2013, kejahatan seksual yang terjadi di Indonesia semakin beragam bentuknya, salah satunya adalah perkosaan anal sex (Komnas Perempuan, 2016:1).

Di sisi lain, para ahli pidana justru menjelaskan bahwa perkosaan anal sex bukanlah perkosaan yang dimaksud dalam pasal 285 KUHP. Perkosaan (verkrachting) secara hukum harus terjadi melalui lubang vagina, karena hanya lubang vagina yang berpotensi menyebabkan kehamilan. 
Penjelasan ini selaras dengan Arrest Hoge Raad 5 Februari 1912 (Soesilo, 1988: 209)

Oleh karena kejahatan perkosaan anal sex itu bukan bagian dari kejahatan perkosaan (verkrachting) yang dimaksud dalam pasal 285 KUHP, maka sebagaimana yang dijelaskan oleh Prof. Simons, kejahatan itu hanya dapat diancam dengan ketentuan pasal 289 KUHP tentang perbuatan cabul (ontuchtige handelingen). Menurut Simons, sebagaimana dikutip oleh Lamintang dan Theo Lamintang (2011: 134) menjelaskan bahwa yang dimaksud dengan perbuatan cabul adalah "Handelingen, welke het geslachtelijk leven betreffende met wellustige boedelingen geschieden en het algemene zedelijkheidsgevoel krenken" (Tindakan yang berkenaan dengan kehidupan dalam bidang seksual, yang dilakukan dengan maksud untuk mendapatkan kesenangan dengan cara yang bertentangan dengan pandangan umum tentang kesusilaan).

Dari kaidah tentang perbuatan cabul tersebut, disimpulkan bahwa pelaku perkosaan anal sex hanya dapat diancam dengan dakwaan yang lebih rendah atau lebih ringan dari pelaku perkosaan melalui lubang vagina (intra vaginal). Mengingat, perkosaan yang diatur dalam pasal 285 KUHP diancam dengan pidana maksimal 12 tahun penjara, sedangkan pencabulan diancam dengan pidana maksimal 9 tahun (pasal 289 KUHP) (Lamintang, 2009:134).

Kenyataan bahwa tidak dikategorikannya perkosaan anal sex sebagai tindak pidana perkosaan (verkrachting) yang dimaksud dalam pasal 285 KUHP ini, sesungguhnya telah melahirkan banyak kritik dari kalangan ahli hukum pidana kontemporer. Dari berbagai kritik tersebut, maka muncullah konsep baru tentang kejahatan perkosaan yang tertuang dalam RUU KUHP. Dalam embrio hukum pidana Indonesia ini, persetubuhan dalam delik perkosaan tidak dibatasi hanya melalui lubang vagina semata.

Di dalam pasal 489 ayat (2) RUU KUHP, seseorang juga dianggap melakukan tindak pidana perkosaan jika ia memasukkan alat kelaminnya ke dalam anus dan mulut wanita atau memasukkan benda yang bukan bagian tubuhnya ke dalam vagina atau anus wanita. Institute for Criminal Justice Reform (2015: 160-161) menyatakan rumusan perkosaan dalam RUU KUHP ini telah mencapai perkembangan karena adanya upaya redefinisi "persetubuhan" yang selama ini tidak berpihak pada korban perkosaan. 
Selain lemah dalam menentukan hukuman pokok pidana, hukum pidana Indonesia pun terlihat tidak berpihak pada korban perkosaan anal sex. Korban tidak serta-merta berhak memperoleh ganti kerugian materil dari pelaku, meskipun pengadilan telah memutus bersalah pelakunya.

Di dalam hukum acara pidana, korban hanya akan dapat memperoleh ganti kerugian ketika korban menjalani mekanisme yang diatur KUHAP atau melalui mekanisme restitusi yang diatur dalam PP No. 44 Tahun 2008 tentang Pemberian Kompensasi, Restitusi, dan Bantuan terhadap Korban dan Saksi.

Secara teoretis, hakim pemeriksa perkara pidana memang tidak dibolehkan untuk menjatuhi hukuman kepada pelaku, untuk membayar restitusi kepada korban, karena adanya asas "hakim pasif" dan asas "ultra ne petita" yang dikenal dalam lingkup hukum perdata. Asas "ultra ne petita" melarang setiap hakim mengabulkan lebih dari yang dituntut, apalagi mengabulkan apa yang tidak dituntut penggugat (Ali dan Heryani, 2012: 65).

Tak hanya itu, restitusi hanya dapat diberikan atas kerugian materil yang dirasakan korban, dan dapat dihitung dan dibuktikan di dalam persidangan (melalui kuitansi pembayaran, dsb), seperti biaya visum korban, pengobatan, konseling, dan terapi lain yang dilakukan. Kerugian yang bersifat immaterial seperti kerugian atas "penggunaan" kemaluan secara melawan hukum (onrechtmatigdaad), kerugian atas efek trauma yang mendalam, dan lain-lain, tidak akan dikabulkan (Harahap, 2010: 82).

Perkosaan anal sex dalam pandangan hukum pidana Indonesia sangatlah berbeda dengan pandangan ulama fikih, baik dari sisi hukuman pokok maupun hukuman tambahan. Namun demikian, meskipun pembahasan ulama fikih tentang perkosaan anal sex telah cukup mendalam, sejatinya pembahasan tersebut hanya merupakan ijtihad yang didasarkan pada dalil yang bersifat umum. Mengingat, di dalam Al-Qur'an maupun hadis tidak terdapat ketentuan yang secara spesifik mengatur tentang perkosaan anal sex.

Di dalam Al-Qur'an, permasalahan tentang hubungan anal sex memang pernah beberapakali disebutkan, namun yang dijelaskan di dalam ayat tersebut adalah hubungan anal sex sesama kaum pria yang dilakukan 
oleh kaum Nabi Lūt (As-Suyuṭī: 495), sebagaimana tertulis dalam surat Al-Árāf ayat 80-81.

Berbeda dengan pandangan hukum KUHP yang lebih meringankan hukuman perkosaan anal sex ketimbang perkosaan intra vaginal, pelaku perkosaan anal sex dalam pandangan fikih jināyāh justru mendapatkan hukuman yang setara dengan pelaku perkosaan intra vaginal, atau bahkan bisa jadi lebih berat, jika mengacu pada pendapat ulama al-Hanafiyyah. Menurut mazhab ini, alasan pemberatan hukuman perkosaan anal sex dilakukan karena sesuai tabiat, anal sex sifatnya lebih buruk daripada hubungan seksual intra vaginal, secara logika hukumannya pun seharusnya lebih berat dari sekedar hadd zina (Ibn Nujaim, t.t.: juz. 5, 28).

Beberapa ulama mazhab al-Ḥanafiyyah memberikan contoh hukuman ta'zīr yang dapat dijatuhkan kepada pelaku perkosaan anal sex. Ibn Nujaim (t.t.: juz. 5, 28), di dalam kitabnya "al-Baḥr ar-Rāiq" menjelaskan bahwa hukuman bagi perkosaan anal sex yang patut diberikan adalah pidana penjara seumur hidup sampai pelaku dinilai telah bertobat, khususnya jika pelaku merupakan pemula. Namun jika pelaku merupakan residivis atas kasus yang sama, maka hukumannya adalah hukuman mati tanpa peduli lagi apakah pelaku berstatus muḥ̣an ataukah gair muḥ̣an.

Berbeda dengan pendapat ulama mazhab al-Ḥanafiyyah, kelompok ulama yang terdiri dari mayoritas ulama asy-Syāfi'iyyah, al-Ḥanābilah dan al-Mālikiyyah, termasuk sebagian kecil ulama mazhab al-Hanafiyyah seperti Abū Yūsuf dan asy-Syaibānī, menyatakan bahwa perkosaan anal sex adalah bagian dari jarīmah az-zinā (sebagai jarīmah al-ḥudūd, bukan jarīmah atta' zīr). Implikasi hukumnya, pelaku dijatuhi vonis ḥadd zina (As-Sarkhasī, 1993: juz. 9, 59). Meskipun terjadi perselisihan pendapat di kalangan ulama mengenai jenis hukuman bagi pelaku perkosaan anal sex, namun para ulama sepakat, hukuman yang dijatuhkan kepada pelaku perkosaan anal sex tidak boleh lebih ringan dari pelaku perkosaan intra vaginal.

Selain penjatuhan vonis hadd zina tersebut, dalam pandangan jumhur ulama, terdapat hukuman lain yang harus dijatuhkan kepada pelaku, yakni membayar mahar kepada korban perkosaan, meskipun hukuman ini masih diperdebatkan oleh sebagian ulama lain. Setelah melihat banyaknya perbedaan hukuman yang ada di antara kedua sistem hukum tersebut, penulis tertarik untuk melakukan penelitian ini dengan mengkomparasikan 
doktrin-doktrin fikih jināyāh dengan hukum pidana positif, agar diketahui perbedaan-perbedaan yang terdapat antara keduanya. Rumusan masalah yang hendak dijawab dalam artikel ini adalah bagaimana pandangan hukum pidana Indonesia tentang hukuman bagi pelaku perkosaan melalui anus (anal sex)? Dan bagaimana pandangan fikih jināyāh tentang hukuman bagi pelaku perkosaan melalui anus ( anal sex)?

\section{B. Pembahasan}

\section{Hukuman-Hukuman Pidana dalam Pandangan Fikih}

Di dalam berbagai karya fikih, pada umumnya ulama mengategorikan perkosaan sebagai jarīmah al-ḥudūd (tt: juz. 2, 343). Di dalam teks syariat sendiri, sejatinya tidak terdapat ayat dan hadis yang secara langsung mengatur tentang hukum dari perkosaan. Namun demikian, kategorisasi perkosaan sebagai bagian dari jarimah al-ḥudūd dilakukan karena dengan dilakukannya perkosaan, maka terpenuhilah unsur jarìmah az-zinā (jarīmah al-ḥudūd). Oleh sebab itu pula, pengistilahan perkosaan di dalam fikih seringkali mengandung redaksi zina, seperti al-ikrāh 'alā azzin dan al-ikrāh bi az-zinā.

Secara umum, para ulama sepakat bahwa sejatinya perkosaan terdiri dari dua unsur hukum, yakni jarīmah az-zin dan unsur paksaan. Hanya saja, dalam perkosaan dengan spesifikasi perkosaan anal sex, para ulama masih berbeda pendapat tentang kategorisasi jarimah-nya. Mayoritas ulama al-Hanafiyyah memberi batasan, zina hanya dapat dikategorikan sebagai jarīmah al-ḥudūd jika hubungan seksual dalam zina itu dilakukan melalui lubang vagina, jika dilakukan melalui lubang anus, perbuatan itu dikategorikan sebagai liwāt, dan hukumannya adalah hukuman ta'zīr (AlKāsānī, 1986: juz. 7, 33).

Sedangkan mayoritas ulama asy-Syāfi'iyyah (Al-Māwardī, 1994: juz. 13, 221), al-Ḥanābilah (Al-Buhūtī, t.t.: juz. 6, 89) dan al-Mālikiyyah (Al-Kharasyī, 1317 H: juz. 8, 75), termasuk minoritas ulama mazhab al-Ḥanafiyyah seperti Abū Yūsuf dan asy-Syaibānī (As-Sarkhasī, 1993: juz. 9, 59), berpendapat bahwa hubungan anal sex dengan wanita ajnabiyah pun tetap dikategorikan jarīmah az-zinā. 
Selain hukuman pokok di atas, terdapat hukuman lain yang wajib dijatuhkan kepada pelaku perkosaan menurut sebagian ulama, yakni kewajiban membayar mahar. Teori tentang mahar sendiri masih menjadi perdebatan di tiga kelompok ulama, yang memiliki pandangan berbeda tentang sebab-sebab seorang wanita berhak memperoleh mahar.

Kelompok ulama pertama memandang bahwa mahar itu merupakan sebuah kompensasi atas penggunaan/penikmatan kemaluan dalam persetubuhan, baik persetubuhan itu terjadi di dalam ataupun di luar ikatan perkawinan yang sah, kecuali hubungan zina (suka sama suka), baik persetubuhan itu dilakukan melalui lubang vagina maupun lubang anus seorang wanita. Dalam pandangan kelompok ini, lubang vagina dan lubang anus adalah sama-sama kemaluan (al-farj).

Ulama yang masuk dalam kelompok ini adalah mayoritas ulama asy-Syāfi'iyyah, yakni Imam asy-Syāfi'ī (Al-Muzannī, 1998: 234), alQalyūbī (1952: juz. 3, 243), an-Nawawī (t.t.: juz. 18, 28) dan ulamaulama mazhab asy-Syāfíiyyah lainnya. Selain itu adapula Majd ad-Dīn Ibn Taimiyyah (t.t.: juz. 2, 39) serta mayoritas ulama mazhab al-Mālikiyyah, seperti Ibn al-Qāsim al-Itqī (Ṣahnūn, t.t.: juz. 16, 13), Ibn al-Qașsāā (Al'Adawī, 1317 H: juz. 8, 76), an-Nimrī al-Qurțūbī (1992: 572), an-Nafrāwī (1998: juz. 1, 184), dan al-Barāżi'î (2002: juz. 4, 676), serta al-Adawī (1989: juz. 1, 274).

Sedangkan kelompok ulama kedua berpendapat bahwa wanita hanya berhak memperoleh mahar jika persetubuhan (kecuali zina) dilakukan melalui lubang vagina, tak peduli apakah persetubuhan itu terjadi di dalam pernikahan yang sah, syubhat maupun perkosaan. Ulama yang berpegang pada teori mahar semacam ini adalah mayoritas ulama mazhab al-Ḥanābilah seperti Musțafā as-Suyūṭī ar-Rahịibanī (t.t.: juz. 5, 224), Ibn Qudāmah (t.t.: juz. 10, 151), Ibn al-Qayyim al-Jauziyyah (t.t.: juz. 5, 687-688) serta Șahnūn, seorang ulama al-Mālikiyyah (Al-Adawī, 1317 H: juz. 8, 76).

Selain dua kelompok ulama tersebut, sebagian ulama lain memandang bahwa konsekuensi hukum pembayaran mahar hanya muncul ketika penggunaan kemaluan terjadi di dalam sebuah ikatan perkawinan yang sah. Segala bentuk penggunaan kemaluan di luar ikatan perkawinan tidak memunculkan kewajiban mahar. Kelompok yang berpedoman pada 
teori ini terdiri dari hampir keseluruhan ulama mazhab al-Ḥanafiyyah (Ibn 'Ābidīn, 2003: juz. 4, 230).

\section{Hukuman-Hukuman Pidana dalam KUHP}

Pasal 10 KUHP menyebutkan bahwa hukuman pidana terdiri dari dua hukuman, yakni hukuman pokok dan hukuman tambahan. Hukuman pidana pokok terdiri dari hukuman mati, hukuman penjara, hukuman kurungan dan hukuman denda. Sedangkan hukuman tambahan terdiri dari pencabutan hak, perampasan barang, dan pengumuman putusan.

Khususnya kejahatan yang berkenaan dengan kesopanan dan kesusilaan (feitelijke aanranding van de eerbaarheid), sebagaimana diatur dalam pasal 289 KUHP, pelakunya diancam dengan hukuman pokok berupa pidana penjara selama-lamanya 9 tahun (Lamintang (2009: 130).

Prof. Simons menjelaskan sebagaimana dikutip oleh Lamintang (2000: 134) menjelaskan bahwa yang dimaksud dengan perbuatan cabul atau perbuatan yang melanggar kesusilaan adalah "handelingen, welke het geslachtelijk leven betreffende met wellustige boedelingen geschieden en het algemene zedelijkheidsgevoel krenken" (Tindakan yang berkenaan dengan kehidupan dalam bidang seksual, yang dilakukan dengan maksud untuk mendapatkan kesenangan dengan cara yang bertentangan dengan pandangan umum tentang kesusilaan).

Lamintang (2000: 135) dan Soesilo (1988: 209) menjelaskan pula bahwa perbuatan cabul merupakan segala jenis kejahatan yang berkaitan dengan nafsu kelamin, yang tidak sampai pada perbuatan persetubuhan, sebagaimana dimaksud dalam pasal 285 KUHP. Sehingga jika seorang pria memasukkan batang penisnya ke dalam lubang anus seorang wanita, kejahatan itu tidak bisa disebut sebagai pemaksaan bersetubuh atau perkosaan, melainkan sebatas perbuatan cabul atau pelanggaran kesusilaan. "Persetubuhan" hanya terjadi ketika pelaku berhasil memasukkan batang penisnya ke dalam vagina dari korban.

Maka dari itulah, menurut Prof. Simons, pencabulan secara hukum dianggap lebih ringan daripada perkosaan. Perkosaan yang diatur dalam pasal $285 \mathrm{KUHP}$ diancam dengan pidana maksimal 12 tahun penjara, 
sedangkan pencabulan diancam dengan pidana maksimal 9 tahun (pasal 289 KUHP) (Lamintang, 2009:134).

\section{Hukuman bagi Pelaku Perkosaan melalui Anus (Anal sex) dalam Pandangan Fikih Jināyāh}

Imam Asy-Syāfíi dan juga jumhur ulama yang mempersamakan antara hukuman perkosaan anal sex (baik terhadap pria maupun wanita), dengan hukuman perkosaan melalui vagina, memang melandaskan pada metode istinbāt yang berbeda dengan metode yang digunakan oleh ulama mazhab al-Hanafiyyah.

Abū Yūsuf dan asy-Syaibānī, sebagaimana dikutip As-Sarkhasī (1993: juz. 9, 77), telah memberikan argumentasi yang cukup baik tentang alasan-alasan jumhur ketika mempersamakan antara hukuman perkosaan melalui anus dan perkosaan melalui lubang vagina, yakni:

1. Perbuatan zina dan liwāt yang dilakukan oleh kaum Lūt disebut di dalam Al-Qur'an sebagai perbuatan al-fākhisyah. Kedua perbuatan ini masuk dalam keumuman nașs tentang perbuatan al-fākhisyah.

2. Zina dan liwāt keduanya disebut sebagai perbuatan al-fākhisyah dikarenakan keduanya memiliki unsur yang sama-sama terpenuhi, yakni masuknya satu al-farj ke dalam al-farj yang lainnya, dengan tujuan menumpahkan sperma pada tempat yang diharamkan.

3. Vagina dan anus sama-sama disebut sebagai al-farj karena syariat tidak membedakan antara keduanya. Dalam pandangan syariat, vagina dan anus sama-sama merupakan aurat yang wajib ditutupi dikarenakan kedua lubang kemaluan tersebut secara tabiat dapat menimbulkan syahwat (musytahā țab'an) jika dipandang, diraba dan dimasuki oleh batang penis. Selain itu, keduanya juga disebut sebagai musytahā țab'an karena organ tubuh wanita itu sama-sama bersifat panas dan lunak, dan sebagian ulama lain menambahkan bahwa keduanya memiliki lubang yang sempit.

Menurut analisa penulis, jenis kias yang digunakan jumhur dalam menetapkan hukuman hadd zina bagi pelaku perkosaan anal sex adalah "al-qiyās fi as-sabab". Dalam masalah anal sex, jumhur berargumen dengan suatu kaidah bahwa penjatuhan vonis hadd zina bukan sematamata didasarkan pada sebuah perbuatan "zina”, melainkan hadd zina itu 
dijatuhkan atas dasar "masuknya kemaluan seseorang kepada kemaluan seseorang lainnya dengan cara haram, jelas-jelas keharamannya, dan secara tabiat menimbulkan syahwat (Al-Gazālī: 1993, juz.1, 330).

Sehingga, ketika sebab penjatuhan hadd zina itu telah terpenuhi, maka pelakunya wajib dijatuhi hadd zina, baik masuknya kemaluan itu dalam rangkaian perbuatan "zina" ataupun "perkosaan", baik kemaluan yang digunakan itu merupakan lubang vagina ataupun anus.

Oleh karena jenis kias yang digunakan adalah al-qiyās fi as-sabab, maka tentu saja mekanisme masalik al-illah yang digunakan dalam kias tersebut adalah tanqīh al-manāt. Imam Al-Qarafi (1973) dalam karyanya Syarh Tanqīh al-Fusul mendefinisikan tanqīḥ al-manāt dengan:

$$
\text { تعيين علة من أوصاف مذكورة }
$$

Menetukan illah dari sifat-sifat yang telah disebutkan

Dengan metode tanqīh al-manāt, jumhur menyamakan lubang vagina dan anus dengan menentukan sifat-sifat yang sama antara keduanya. Setelah menemukan banyaknya sifat yang sama antara keduanya, jumhur kemudian mendapati teks syariat tidak pernah membedakan antara lubang vagina dan anus. Alhasil, jumhur menyimpulkan bahwa syariat memang membedakan antara kedua lubang kemaluan tersebut, termasuk konsekuensi hukum yang berkenaan dengan kedua lubang kemaluan tersebut.

Penggunaan metode al-qiyās fi as-sabab dalam istinbāt hukum tidak disepakati oleh seluruh ulama. Penggunaan metode ini secara umum diterima oleh mayoritas ulama asy-Syāfi'iyyah dan sebagian ulama al-Ḥanābilah, sedangkan ulama lainnya yang menolak dengan tegas penggunaan kias ini adalah mayoritas ulama mazhab al-Ḥanafiyyah dan Abu Dawud Ad-Dabusi (Ibn Qudamah: 2002, juz. 2, 293).

Pendapat mazhab al-Ḥanafiyyah yang menolak kias dalam hudūd adalah lebih lemah dibandingkan pendapat jumhur. Terdapat beberapa argumen yang dapat melemahkan pendapat mazhab ini. Pertama, teks syariat yang menjadi landasan utama penjatuhan hukuman hadd zina masih bersifat global dan membutuhkan kias dalam penerapannya jika kasus yang terjadi belum pernah terjadi di masa tasyri'. 
Kedua, penolakan kias terhadap ḥudūd menunjukkan inkonsistensi mazhab ini dalam ijtihad mereka, karena mazhab ini pun menerima produk fikih yang dilandaskan pada kias, misalnya saja dalam penentuan jumlah cambukan bagi peminum khamr sebanyak 80 cambukan (Ibn Nujaim, 1997: juz. 5, 47).

Padahal sejak zaman Nabi hingga awal masa pemerintahan 'Umar, jumlah hukuman cambuk adalah 40 kali cambukan saja. Berubahnya jumlah cambukan dari 40 kali menjadi 80 kali, adalah merupakan usulan dari 'Abd ar-Raḥmān bin 'Auf berdasarkan kias beliau pada jumlah cambukan pelaku qażaf. Usulan 'Abd ar-Raḥmān bin 'Auf ini pun diterima dan diterapkan oleh 'Umar, hingga kemudian menjadi ijma di kalangan sahabat ('Audah, t.t.: juz. 2, 507).

Penerimaan mazhab al-Ḥanafiyyah atas keputusan 'Umar yang notabene bermula dari kias 'Abd ar- Raḥmān bin 'Auf ini menunjukkan adanya inkonsistensi dalam menerapkan prinsip penolakan kias dalam hudūd. Jika ingin konsisten dengan pendapat mazhabnya, maka seharusnya hukuman hadd khamr adalah 40 kali cambukan saja sesuai sunnah Rasul, bukannya mengikuti hasil kias 'Abd ar- Raḥmān bin 'Auf .

Ketiga, pendapat mazhab al-Ḥanafiyyah berkonsekuensi pada pendapat yang aneh. Dengan tidak disamakannya konsekuensi hukum lubang vagina dan anus, secara tidak langsung mereka menyamakan hukum dari lubang anus wanita dengan organ tubuh wanita lainnya. Misalnya, seseorang melakukan anal sex dengan isterinya ketika berpuasa, maka puasa tersebut tidak batal sepanjang belum ejakulasi, karena batang penisnya tidak dimasukkan ke dalam lubang vagina, hukumnya sama seperti berciuman dan berpelukan.

Padahal terdapat perbedaan hukum yang signifikan antara interaksi fisik terhadap lubang anus dan bibir wanita. Sesuai tabiat, lubang anus wanita lebih menggairahkan dibandingkan bibir wanita. Lubang anus merupakan aurat berdasarkan ijma', namun bibir wanita menurut jumhur bukanlah aurat yang wajib ditutupi.

Terlepas dari ikhtilaf ulama di atas, sejatinya seluruh ulama sepakat menyatakan keharaman perbuatan anal sex, apalagi dengan perkosaan. Perbedaan yang muncul di atas hanya terletak pada aspek furūiiyyah, 
yakni pada jenis hukuman. Salah dan benarnya ijtihad mereka, sama-sama mendapat pahala, meskipun yang benar mendapat porsi ganda.

\section{Hukuman bagi Pelaku Perkosaan melalui Anus (Anal sex) dalam Pandangan Hukum Pidana Indonesia}

\section{a. Hukuman Pokok}

Mengacu pada jenis-jenis hukuman dalam KUHP, konsep peradilan yang menonjol dalam KUHP adalah peradilan yang mengutamakan keadilan retributif. Mengingat seluruh jenis hukuman pidana dalam KUHP hanya memfokuskan pada penghukuman pelaku kejahatan, menangani tata tertib publik (public order) dan cenderung tidak memperhatikan posisi korban dalam penegakan hukum.

Kalaupun terdapat regulasi yang mengatur tentang restitusi sebagai sebuah hukuman yang dapat dibebankan kepada pelaku, namun hukuman ini tidak dijadikan sebagai hukuman pidana melainkan sebagai hukuman yang bersifat keperdataan, yang tentu saja memiliki daya paksa yang berbeda.

Berkenaan dengan hukuman pokok, hukum pidana Indonesia memiliki doktrin tentang pembedaan lubang vagina dan anus sebagai objek persetubuhan perkosaan. Perkosaan yang dilakukan melalui lubang vagina diancam dengan hukuman maksimal 12 tahun penjara sesuai pasal 285 KUHP, sedangkan perkosaan anal sex diancam dengan hukuman penjara 9 tahun penjara sesuai pasal $289 \mathrm{KUHP}$, terdapat selisih tiga tahun lebih ringan dari perkosaan intra vaginal.

Pembedaan hukuman ini jelas-jelas merugikan kaum wanita yang selalu berposisi menjadi korban dalam setiap tindak pidana perkosaan. Pembedaan hukuman ini pun sudah selayaknya ditinjau ulang dengan beberapa pertimbangan berikut:

1. Bentuk-bentuk perkosaan yang terjadi pada akhir-akhir ini sudah semakin kompleks, sedangkan rumusan perkosaan dan pencabulan di dalam KUHP belum pernah direvisi sama sekali hingga sekarang. 
2. Dampak luka akibat perkosaan melalui anus lebih besar dibandingkan perkosaan intra vaginal dikarenakan lubang anus tidak selayaknya dijadikan tempat/jalur persetubuhan.

3. Selain menimbulkan luka yang lebih parah pasca persetubuhan, hubungan anal sex lebih berpotensi memberikan penyakit kepada korban begitupula pelaku, dibandingkan dengan hubungan seksual intra vaginal.

4. Pembedaan hukuman kedua jenis perkosaan ini dapat membuat calon pelaku dapat memilih alternatif perkosaan yang lebih ringan hukumannya, yakni perkosaan anal sex. Hal ini tidak akan terjadi jika hukuman kedua jenis perkosaan ini disamakan dengan, atau bahkan diperberat hukumannya.

Para ahli hukum pidana kontemporer dan beberapa aktifis gender telah berulang kali mengritik kebijakan negara dalam mengategorikan perkosaan sebagai delik kesusilaan. Ketua LBH APIK, Veronica, dalam salah satu rubrik yang ditulis dalam Berita Komnas Perempuan (edisi. 7: 2011, 7) menyatakan bahwa perkosaan seharusnya tidak lagi dianggap hanya sebatas pelanggaran kesusilaan atau moral, karena perkosaan merupakan pelanggaran serius terhadap hak-hak wanita. Untuk saat ini perlu ada undang-undang yang secara tersendiri mengatur tentang kejahatan seksual.

Dampak lain dari pengategorian perkosaan dalam delik kesusilaan, dan bukan masuk dalam kategori delik terhadap tubuh adalah munculnya anggapan bahwa perempuan hanya sebatas pemuas seksual lelaki. Perempuan tidak lagi didudukkan sebagai seorang manusia yang berhak terlindungi kehormatannya oleh negara. Dengan kata lain, negara tidak bersungguh-sungguh melindungi wanita, namun lebih bersungguhsungguh dalam menjaga kesusilaan dan kesopanan di tengah masyarakat.

Berkaitan dengan kadar penghukuman pada pelaku perkosaan anal sex yang hanya selama maksimal 9 tahun penjara, hukuman ini pun masih jauh dari kelayakan. Jika negara benar-benar konsisten dengan upaya perlindungan korban, maka seharusnya perlu dikaji lebih lanjut apakah hukuman itu sudah dianggap dapat memberikan efek jera kepada pelaku? 


\section{b. Hukuman Ganti Kerugian dan/atau Restitusi}

Selain berperan sebagai lembaga yang memvisualkan nilai viktimologi dalam penegakan hukum (Muladi, 2002: 175), restitusi juga merupakan sebuah hukuman (keperdataan) yang dijatuhkan kepada pelaku perkosaan. Maka dari itulah, kajian tentang mekanisme pengajuan restitusi merupakan salah satu tema penting dalam penelitian ini, guna mengetahui bagaimana negara menjatuhkan hukuman baik dari aspek maupun non fisik kepada pelaku perkosaan.

Pemerintah sejatinya telah memfasilitasi kepentingan korban perkosaan anal sex dengan diaturnya mekanisme pengajuan gugatan ganti kerugian bagi korban tindak pidana, baik dengan menggunakan prosedur bab XIII KUHAP, maupun melalui prosedur PP. No. 44 Tahun 2008 tentang pemberian kompensasi, restitusi, dan bantuan kepada saksi dan korban. Pemerintah pun secara khusus telah mendirikan LPSK (UU No. 13, 2006) untuk melindungi kepentingan korban di dalam pengadilan sebagaimana digariskan dalam PP. no. 44 tahun 2008.

Meskipun demikian, di dalam praktik, konsep perlindungan korban versi pemerintah ini masih menyisakan beberapa persoalan di dalam praktik. Korban tindak pidana kesusilaan misalnya, secara psikologis korban kejahatan ini hampir mustahil mampu mengajukan gugatan perdata ke hadapan sidang, apalagi harus menceritakan secara detil tentang kekerasan seksual yang mereka alami.

Pasca terjadinya perkosaan, korban akan mengalami Post Traumatic Stress Disorder (PTSD), yakni sebuah kondisi psikologis di mana seorang korban mengalami gangguan kecemasan selama lebih dari 30 hari akibat peristiwa traumatis yang dialami korban perkosaan (Sulistyaningsih \& Faturochman: 2002, 12).

Salah satu reaksi yang muncul pada diri korban adalah sikap menutup diri dan tidak mau menceritakan pengalamannya kepada orang lain (Sulistyaningsih \& Faturochman: 2002, 10). Kondisi psikologis korban inilah yang nampaknya tidak sempat terpikirkan oleh pembuat undang-undang. Bagaimana mungkin seorang korban perkosaan yang sedang mengalami trauma hebat disarankan untuk mengajukan gugatan ganti kerugian di hadapan persidangan? 
Tak hanya itu, tugas pokok dan fungsi LPSK yang digadang-gadang dapat melindungi dan mengadvokasi kepentingan korban perkosaan pun di dalam praktik tidak berjalan seideal yang diharapkan undang-undang. Tidak maksimalnya tugas pokok dan fungsi LPSK disebabkan karena pemerintah tidak memberikan dukungan anggaran yang cukup serta alokasi SDM yang memadai pada LPSK. Padahal, guna memaksimalkan peranan LPSK, pemerintah harus mampu memberikan anggaran yang cukup banyak serta personil LPSK yang mumpuni, sehingga mampu mendampingi para korban tindak pidana di seluruh Indonesia.

Hasto Atmojo Suroyo di dalam Majalah Kesaksian (2015: 3738) mengungkapkan beberapa problematika yang dihadapi LPSK dalam praktik pengadilan:

"LPSK baik sebagai kelembagaan, SDM maupun anggaran, sangat tidak memadai. Misalnya, LPSK hanya memiliki tujuh orang komisioner ditambah sekitar 200 karyawan yang harus memberikan perlindungan kepada saksi dan korban, layani seluruh Indonesia.

"Jadi, kadang-kadang kami pikir negara ini kurang besungguh-sungguh ya mendirikan suatu lembaga tapi tidak diberikan suatu fasilitas yang memadai untuk itu," katanya setengah mengeluh.

Kalau LPSK harus mengikuti proses peradilan, itu yang menyulitkan, karena LPSK di satu sisi harus ke berbagai daerah, di sisi lain jumlah personilnya terbatas. Anggaran yang tersedia pun terbatas, hanya Rp 60 miliar pertahun.

Untuk itu, lembaga ini membuat skala prioritas. Artinya, mereka memberikan perlindungan kepada saksi dan korban yang berdimensi struktural atau kasus yang berdimensi luas; mempunyai dampak kemasyarakatan yang luas. Atau kalau kasusnya individual, menarik perhatian banyak orang. Namun demikian, bukan berarti LPSK tidak memperhatikan kasus individual, misalnya perkosaan. Tapi kalau LPSK harus menangani kasus-kasus itu secara fullspeed, tidak mungkin karena keterbatasan berbagai hal tersebut".

Problem semacam inilah yang dialami korban tindak pidana di dalam praktik pengadilan. Problem semacam ini tidak akan menimpa korban jika pemerintah menetapkan ganti kerugian sebagai hukuman pokok pidana.

Maka dari itu, penulis sangat setuju dengan adanya konsep hukuman pidana tambahan yang ditawarkan oleh pasal 67 ayat (1) huruf (d) dan (e) RUU KUHP, di mana pembayaran ganti kerugian dan pemenuhan kewajiban adat setempat dan/atau kewajiban menurut hukum yang hidup di dalam masyarakat, menjadi bagian dari hukuman pidana 
yang secara imperatif dapat dijatuhkan hakim kepada pelaku (tanpa perlu menunggu gugatan perdata). Konsep pemidanaan semacam inilah yang menurut penulis dapat memecahkan permasalahan perlindungan korban perkosaan.

\section{Persamaan dan Perbedaan Hukuman Pidana Perkosaan antara Fikih Jināyāh dan Hukum Pidana Indonesia}

Dari seluruh materi-materi hukum yang telah penulis jelaskan di atas, dapat disimpulkan bahwa terdapat beberapa persamaan dan perbedaan antara hukum fikih dan hukum pidana Indonesia tentang hukuman perkosaan anal sex. Jika dikomparasikan dengan doktrin fikih yang ada, doktrin pembedaan lubang vagina dan anus yang terdapat dalam hukum pidana Indonesia ini sangat mirip dengan doktrin yang dianut oleh mayoritas ulama mazhab al-Ḥanafiyyah.

Hukum pidana Indonesia dan mazhab al-Ḥanafiyyah sama-sama membedakan antara hukuman perkosaan intra vaginal dan perkosaan anal sex. Dari sisi kadar hukuman, kedua sistem ini pun sama-sama menjatuhkan hukuman yang relatif lebih ringan bagi pelaku perkosaan anal sex dibandingkan perkosaan intra vaginal. Perbedaannya, di dalam hukum fikih mazhab al-Ḥanafiyyah, perkosaan intra vaginal diancam dengan hadd zina, dan perkosaan anal sex diancam dengan penjatuhan hukuman ta'zir, sedangkan bentuk hukuman pidana yang dianut dalam sistem hukum Indonesia adalah hukuman penjara maksimal 9 tahun sesuai pasal 289 KUHP.

Tak hanya dalam aspek hukuman pidana pokok, hukum pidana Indonesia dan mazhab al-Ḥanafiyyah pun sama-sama tidak mengatur adanya hukuman tambahan berupa hukuman pembayaran ganti kerugian atau yang semacamnya bagi pelaku perkosaan anal sex. Meskipun landasan doktrin keduanya berbeda, namun konklusi hukum keduanya dalam masalah hukuman ganti kerugian ini adalah sama saja.

Sedangkan jika doktrin hukum pidana Indonesia diperbandingkan dengan doktrin yang dianut oleh jumhur ulama fikih, maka akan ditemukan hal yang sangat kontras berbeda. Sejak semula jumhur ulama fikih tidak membedakan antara hukum vagina dan anus, dan oleh karenanya tidak ada perbedaan antara perkosaan intra vaginal dan perkosaan anal sex. Dalam pandangan jumhur, kedua bentuk perkosaan itu merupakan sebuah 
kejahatan yang diganjar dengan hukuman yang sama beratnya, yakni hadd zina.

Tak hanya itu, dalam fikih jumhur, nilai-nilai viktimologi sangat kental terlihat dalam pendapat hukum mereka. Korban perkosaan didudukkan sebagai seorang manusia yang memiliki hak-hak asasi yang harus dipenuhi jika terampas secara zalim oleh pelaku perkosaan. Hakhak asasi yang dimaksud tentu saja adalah hak mahar sebagai kompensasi atas persetubuhan. Dalam pandangan jumhur, mahar tidak hanya semata digunakan dalam perbuatan hukum pernikahan. Mengingat, dalam pandangan jumhur, mahar itu sejatinya merupakan hak wanita yang harus ia peroleh jika disetubuhi oleh seorang lelaki, baik dalam pernikahan yang sah ataupun di luar pernikahan yang sah, asalkan bukan perzinaan.

Nilai-nilai viktimologi inilah yang tidak dapat ditemukan dalam doktrin hukum pidana Indonesia. Sebagaimana penulis jelaskan di atas, fokus kepentingan pemerintah dalam sebuah penegakan hukum bukanlah untuk memenuhi hak-hak korban tindak pidana, melainkan penghukuman pelaku dan penegakan ketertiban susila di tengah masyarakat. Padahal, jika saja pemerintah menjadikan doktrin fikih jumhur ulama ini sebagai panutan/percontohan, maka pemerintah dapat mencapai dua target dalam sekali bekerja menegakkan hukum. Rasanya bukanlah suatu hal yang mustahil bagi pemerintah untuk mencontoh doktrin fikih jumhur tersebut.

\section{Simpulan}

Dari seluruh pembahasan yang telah penulis sampaikan, penulis menghasilkan dua kesimpulan. Pertama, di dalam pandangan fikih, meskipun terdapat perselisihan di kalangan ulama tentang hukuman perkosaan anal sex, namun yang lebih rājị adalah yang disampaikan oleh jumhur, yakni hukuman hadd zina. Selain hukuman pokok itu, terdapat pula hukuman tambahan berupa pembayaran mahar kepada korban.

Kedua, menurut hukum pidana Indonesia, hukuman bagi pelaku perkosaan anal sex adalah pidana penjara maksimal 9 tahun sebagaimana diatur dalam pasal 289 KUHP tentang perbuatan cabul (ontuchtige handelingen). Hukuman ini lebih ringan dari perkosaan intra vaginal yang diancam dengan pidana penjara maksimal 12 tahun, sebagaimana diatur dalam pasal $285 \mathrm{KUHP}$. Selain itu, tidak terdapat hukuman pidana tambahan berupa pembayaran ganti kerugian materil kepada korban. 


\section{BIBLIOGRAFI}

Ad-Dimasyqī, Ibn ‘Ābidīn Al-Ḥanafī, 1202 H, Radd al-Muhtār 'alā ad-Durr al-Mukhtār, Beirut: Dār al-Fikr.

Al-Adawī, 'Alī bin Aḥmad aṣ-Ṣāidi, 1317 H, Hạasyiyyah al-'Adawì 'alā Manh al-Jalī Syarh Mukhtaṣar Khalil, t.t.p: Al-Maṭba'ah al-Kubrā al-Amïriyyah.

Al-Adawī, 'Alī bin Ahmad aṣ-Ṣāiodi, 1994, Ḥāsyiyyat al-'Adawĩ 'alā Kifāyah aț-Tâlib ar-Rabbān , Beirut: Dar al-Fikr.

Al-Barāżi î̀, Khalaf bin Abī al-Qāsim Muhammad al-Azadī al-Qairuwānī, 2002, At-Tahżīb fī Ikhtișāri al-Mudawwanah, Dubai: Dār al-Buhūs wa ad-Dirāsāt.

Al-Barkatī, As-Sayyid Muhạmmad 'Amīm al-Ihsān al-Mujaddidī, 2003, AtTárîfāt al-Fiqhiyyah, Beirūt: Dār al-Kutub al-Ilmiyyah.

Al-Buhūtī, Manșūr bin Yūnus bin Idrīs, t.t.a, Kasysyāf al-Qinā' 'an Matan al-Iqnā', Beirūt: 'Ālim al-Kutub.

Al-Buhūtī, Manșūr bin Yūnus bin Idrīs,t.t.b, ar-Raud al-Murbi' Syarh Zād al-Mustaqni' fì Ikhtișāri al-Muqni', T.t.p: Muassasah Ar-Risalah.

Al-Bujairamī, Sulaimān bin Muḥammad, 1345 H, Ḥāsyiyyah al-Bujairamī 'alā Manhāji aț-Tullāb, Mesir: Matba'ah Al-Mustafā Al-Halabī.

Al-Busīīī, Syihāb ad-Dīn, 1998, Miṣbāh az-Zujājah fī Zawāid Sunan Ibn Mājah li Abì 'Abd Allah Muhammad bin Yazìd al-Qazwain, Riyāḍ:Maktabah al-Maārif.

Al-Fayūmī, Aḥmad bin Muhammad bin Alī, al-Miṣbāh al-Mun r, Beirut: Maktabah Libanon, 1987.

Al-Gazālī, Abu Hamid, 1993, Al-Mustashfa, Beirut: Dar al-Kutub alIlmiyyah.

Al-Ḥarrānī, Abū al-Barakāt Majd ad-Dīn 'Abd as-Salām bin 'Abd Allah Ibn Taimiyyah, t.t., al-Muharrar fī Fiqh Imam Aḥmad bin Hanbal, Saudi: Wuzārah asy-Syu'ūn al-Islāmiyyah wa al-Auqāif.

Al-Husainī, Muḥammad bin Muhammad bin 'Abd ar-Razzāq, Tāj al-'Urūs min Jawāhir al-Qāmūs, Kuwait: Matba'ah Hukumah Kuwait: 1969. 
Ali, Achmad dan Wiwie Heryani, 2012, Asas-Asas Hukum Pembuktian Perdata, Jakarta: Prenadamedia Group.

Al-Jamāl, Sulaimān bin 'Umar, t.t., Hāasyiyyah al-Jamāl 'alā Syarh Manhaj aț-Tullāb, Beirut: Dār Ihya at-Turas.

Al-Jauziyyah, Ibn Qayyim, t.t., Zād al-Ma'ād, Beirūt: Muassasah ArRisalah.

Al-Kāsānī ', Abū Bakr bin Mas'ūd bin Aḥmad, 1986, Badā'i' as-Ṣanāi' fī Tartībi asy-Syarāi', Beirut: Dar al-Kutub al-Ilmiyyah.

Al-Kharasyī, Abū 'Abd Allah Muhammad, 1317 H, Syarh Mukhtaṣar Khalīl, t.t.p: Al-Maṭba'ah al-Kubrā al-Amīriyyah.

Al-Magribī, Syams ad-Dīn Abū 'Abd Allah bin Muhammad bin 'Abd arRaḥmān at-Ṭarābalsī, t.t., Mawāhibu al-Jalīl li Syarh Mukhtaṣar Khalīl, Beirūt: Dār 'Ālim al-Kutub.

Al-Maqdisī, Abū Muhammad 'Abd Allah bin Ahmmad bin Maḥmud bin Qudāmah, t.t., Al-Mugnī, t.t.p: Dar al-Kitab al-Arabi.

Al-Māwardī, al-'Allāmah Abū Hạan, 1994, al-Ḥ̂āì al-Kabìr, Beirūt: Dār al-Kutub al-Ilmiyyah.

Al-Miṣrī, Ibn Nujaim, Zain ad-Dīn bin Ibrāhīm, t.t., al-Baḥr ar-Rā'iq Syarh Kanz ad-Daqā’iq, Beirūt: Dār al-Kutub al-Ilmiyyah.

Al-Muțarrazī, Ibnu 'Alī, Nāṣir bin 'Abd as-Sayyid Abī al-Makāim, alMugrab fī Tartībi al-Mū'rab, Suriah: Maktabah Usamah bin Zaid, tt.

Al-Muzannī, Abū Ibrāhīm, 1998, Mukhtaṣar al-Muzann (Beirūt: Dār AlKutub Al-Ilmiyyah.

Al-Qalyūbī, Syihāb ad-Dīn Aḥmad Salāmah dan Aḥmad al-Barlāsi 'Umairah, 1952, Hạasyiyyatā Qalyūbì wa 'Umairah, T.t.p: Syirkah Maktabah wa Matba’ah Mustafa Al-Halabi.

Al-Qarafi, Abu Al-Abbas Syihab ad-Din, 1973, Syarh Tanqīh al-Fusul, Beirut: Syirkah At-Tabaah al-Fanniyyah.

Al-Qurțūbī, Abū 'Umar Yūsuf bin 'Abd Allah bin Muhammad bin 'Abd alBarr bin 'Āsim an-Nimrī, 1992, al-Käfī fì Fiqhi Ahli al-Madīnah alMalikī, Beirūt: Dār al-Kutub al-Ilmiyyah. 
al-Urnī, Asy-Syāfi ì, Muhammad al-Amīn bin 'Abd Allah, 2009, al-Kaukab al-Wahhāj wa Rauḍah al-Bahhāj fi Syarḥ Șahīh Muslim bin al-Hajjāj, Beirut: Dār Tauq An-Najāh.

Anggara dan Ajeng Gandini Kamilah (ed)., 2015, Catatan terhadap Beberapa Ketentuan Dalam Rancangan KUHP, Jakarta: Institute For Criminal Justice Reform.

An-Nafrāwī, Aḥmad bin Gunaim bin Sālim, 1998, al-Fawākih ad-Dawān̄̄ 'alā Risālati Ibn Ab̄i Zaid al-Qairuwānī, Beirūt: Dār al-Kutub al'Ilmiyyah.

An-Nawawī, Muhyī ad-Dīn Abī Zakariyyā bin Syaraf, 2005, Minḥāj at-Tălibìn wa 'Umdah al-Muftìn, Beirūt: Dār al-Minhāj.

An-Nawawī, Muhyyī ad-Dīn Abī Zakariyyā bin Syaraf, t.t., Al-Majmū’ Syarh al-Muhażżab li asy-Syīrāz , Jeddah: Maktabah Al-Irsyād.

Arikunto, Suharsimi, 1998, Prosedur Penelitian, Suatu Pendekatan Praktek, Jakarta: Rineka Cipta.

Ar-Rahịibanī, Musțafā bin Sa'd bin 'Abduh As-Suyūṭī al-Ḥanbalī, t.t., Maṭālib Ūlì an-Nuhā fī Syarh Gāyah al-Muntah , Beirūt: Dār AlKutub Al-Ilmiyyah,.

Aṣ-Ṣanānī, 'Abd ar-Razzāq, 1972, Muṣannaf 'Abd ar-Razzāq, Beirut: Majlis al-Ilmi.

As-Sarkhasī, Muhammad bin Aḥmad bin Sahl, 1993, al-Mabsūt, Beirūt: Dār al-Ma'rifah.

As-Suyuṭī, Ibn Abī Bakr., t.t., Ad-Durr al-Manisur, Beirut: Dār al-Fikr.

Asy-Syāfi'ì, Muhạmmad bin Idrīs, 2001, Al-Umm, t.t.p: Dar Al-Wafa.

At-Tanūhī, Șahnūn bin Saīid, t.t., al-Mudawwanah al-Kubr , Saudi: Wuzārah asy-Syu ūn al-Islāmiyyah wa al-Auqāf.

At-Tirmiż̄̄, Abu Isā, t.t, Jami'At-Tirmiż , Riyāḍ:International Ideas Home.

'Audah, 'Abd al-Qādir, at-Tasyrī' al-Jināì Muqāran bi al-Qānūn al-Waḍ', Beirūt: Dār ' al-Kutub al-'Arabī, tt.

Az-Zuhailīi, Wahbah, Al-Fiqh Al-Islāmī wa Adillatuhu, Beirūt: Dār Al-Fikr, 1985.

Departemen Pendidikan dan Kebudayaan, Kamus Besar Bahasa Indonesia, Jakarta: Balai Pustaka, 1990. 
Eddyono, Supriyadi Widodo dan Indry Oktaviani, Kejahatan Perkosaan dalam RUU KUHP, Jakarta: ELSAM dan TIFA, 2007.

Hamzah, Andi, Asas-Asas Hukum Pidana di Indonesia dan Perkembangannya, Medan: Sofmedia, 2012.

Harahap, M. Yahya, 2010, Pembahasan Permasalahan dan Penerapan KUHAP: Pemeriksaan sidang Pengadilan, Banding, Kasasi, dan Peninjauan Kembali, Jakarta: Sinar Grafika.

Hiariej, Eddy Omar Sharief., Prinsip-Prinsip Hukum Pidana, Yogyakarta: Cahaya Atma Pustaka, 2014.

Khān, Musțafā Sa īd, 1998, Asar Ikhtilaffi al-Qawaid al-Usuliyah fi Ikhtilaf al-Fuqaha, Beirut: Muassasah ar-Risalah.

Lamintang, P.A.F dan Theo Lamintang, 2009, Kejahatan Melanggar Norma Kesusilaan dan Norma Kepatutan, Jakarta: Sinar Grafika.

Lamintang, P.A.F dan Theo Lamintang, Dasar-Dasar Hukum Pidana di Indonesia, Jakarta: Sinar Grafika, 2014.

Mālik, ibn Anas ibn Mālik, al-Muwaț̣a', Beirūt: Dār Ihyā At-Turās, 1985.

Marpaung, Leden, 1997, Kejahatan Terhadap Kesusilaan dan Masalah Prevensinya, Jakarta, Penerbit Sinar Grafika.

Nakarī, Al-Qādịi 'Abd Rabb an-Nabī bin 'Abd Rabb ar-Rasūl al-Aḥmad, 2000, Dustūr al-'Ulamā', Beirūt: Dār al-Fikr.

Nazir, Muh., 1999, Metode Penelitian, Jakarta: Ghalia Indonesia.

Peraturan Pemerintah Nomor 44 Tahun 2008 tentang Pemberian Kompensasi, Restitusi, dan Bantuan Kepada Saksi dan Korban.

Qubhā, Bāsil Muhammad Yūsuf, 2009, at-Ta'wị̀ 'an ad-Darar al-Adab , Tesis (Online), Palestina: Jāmi'ah an-Najāh al-Wațaniyyah, (http://scholar.najah.edu/sites/scholar.najah.edu/files/allthesis/identifyin the_literary_harmful.pdf, (diakses pada tanggal 1 Februari 2013).

Sakidjo, Aruan dan Bambang Poernomo, Hukum Pidana, Jakarta: Ghalia Indonesia, 1990.

Soekanto, Soerjono, 1984, Pengantar Penelitian Hukum, Jakarta: Universitas Indonesia. 
Soesilo, R., 1988, KUHP serta Komentar-Komentarnya Lengkap dengan Pasal demi Pasal, Bandung: Karya Nusantara.

Sugandhi, R., 1981, KUHP dan Penjelasannya, Surabaya: Usaha Nasional. Sulistyaningsih, Ekandari dan Faturochman, 2002, "Dampak Sosial Psikologis Perkosaan", Buletin Psikologi.

Suprayogo, Imam, dkk., 2001, Metodologi Penelitian Sosial-Agama, Bandung: PT. Remaja Rosdakarya.

Suroyo, Hasto Atmojo, 2015, "LPSK Tak Ingin Terjepit dengan Dana Irit”, Majalah Kesaksian. 